\title{
Population genetics of French brown trout (Salmo trutta L) : large geographical differentiation of wild populations and high similarity of domesticated stocks
}

\author{
Francine KRIEG and R. GUYOMARD \\ I.N.R.A., Laboratoire de Physiologie des Poissons \\ Centre de Recherches zootechniques \\ F 78350 Jouy-en-Josas
}

\begin{abstract}
Summary
The genetic variability of 7 fish-farm strains and 14 wild populations of brown trout was studied by electrophoretic analysis of 23 enzyme systems coded for by 52 loci. The total gene diversity was high (0.112) as compared to other salmonid species, but only 45 p. 100 was found within the populations, indicating an extreme genetic differentiation in brown trout. UPGMA clustering analysis subdivided the populations into 4 major groups, i.e. 2 in Corsica, 1 in Brittany and a 4 th one closely clustering the Norman wild anadromous populations with the hatchery strains. These results suggest that Breton and Corsican samples represent native stocks, but that some hatchery introgression or contamination is possible in Norman rivers. This last assumption could explain the coexistence of 2 electrophoretically differentiated ecotypes in one Norman drainage. The genetic distances between Corsican and continental samples are consistent with previous meristic studies reporting the occurrence of a differentiated form in Corsica.

According to the heterozygosity level and genetic distance values, a severe bottleneck effect is unlikely to have occurred except in one of the wild populations. The hatchery strains showed a high genetic similarity which could be interpreted as a founder effect by an initial sampling in a restricted area of the species range.
\end{abstract}

Key words : Electrophoretic variation, population genetics, Salmo trutta $L$.

\section{Résumé}

Génétique des populations françaises de truite fario (Salmo trutta $L$.) : forte différenciation géographique des populations naturelles et similitude génétique des souches d'élevage

La variatibilité électrophorétique de 23 systèmes codés par 52 locus a été examinée dans 7 souches de piscicultures et 14 populations naturelles de truite fario. Par rapport à d'autres espèces de salmonidés, la truite fario se distingue par une variabilité totale élevée $(0,112)$ et un fort degré de différenciation interpopulation, la variabilité intrapopulation ne représentant que 45 p. 100 de la variabilité totale. L'analyse des distances génétiques par agglomération hiérarchique UGPMA fait apparaître 4 principaux groupes, 2 en Corse, 1 en Bretagne et un $4^{\mathrm{e}}$ regroupant les populations naturelles normandes et les souches de pisciculture. Ces résultats suggèrent que les échantillons corses et bretons 
représentent des stocks autochtones, mais que des phénomènes de contamination ou d'introgression ont $\mathrm{pu}$ se produire dans les rivières normandes. Ces phénomènes pourraient bien être à l'origine de la coexistence de deux écotypes génétiquement distincts dans l'Orne (Normandie). Les distances génétiques entre populations corses et continentales sont cohérentes avec des études méristiques antérieures indiquant la présence d'une forme différenciée en Corse. Les valeurs des taux d'hétérozygotie et des distances génétiques suggèrent que ces populations naturelles, à l'exception d'une, n'ont subi aucune perte importante de variabilité par dérive génétique.

Par contre, les souches domestiques étudiées constituent un ensemble peu différencié. Ceci pourrait résulter d'un effet fondateur dû à un échantillonnage initial dans une airc restreinte du domaine de l'espèce.

Mots clés : Variations électrophorétiques, génétique des populations, Salmo trutta.

\section{Introduction}

Some general biological and historical features of salmonids are, a priori, in favour of the appearance of evolutionary divergences, i.e. (1) a large species range (Mac Crimmon \& Marshall, 1968), (2) a subdivision of this area into independent hydrographic drainages, the geographic isolation between migratory forms being maintained by homing, and (3) the occurrence of multiple colonizations corresponding to different geological periods (quaternary glaciations) (GELDIAY, 1972 ; BEHNKE, 1968, 1972).

In brown trout, these factors seem to have been amply operative when considering the extreme phenotypic diversity and the large number of geographical and ecological forms described (BEHNKE, 1968, 1972). However, all these arguments, although suggesting the possible existence of differentiations, do not constitue proofs of genetic divergences. On the one hand, the biological characteristics and historical conditions could have been inefficient. Homing is not complete and erratic individuals always occur (THORPE \& Mrtchell, 1981). It seems that migration at the rate of one migrant individual per local population per generation is generally sufficient to obscure any disruptive effect of drift (SPIETH, 1974). This does not mean that such a migration rate is sufficient to maintain statistically identical allele frequencies between populations (Allendorf \& Phelps, 1981). Successive colonizations by genetically different forms could lead to the elimination of some of these forms through competition or introgression. On the other hand, the recognition of ecological or geographical forms is based on phenotypic differences of characters, the variation of which could be strongly influenced by the environment.

In fact, evidence of a large genetic differentiation between brown trout populations has been provided by the electrophoretic approach. These studies, up to now limited to a small part of the species range, Scandinavia, British Isles and France, have revealed the extreme geographical diversity within this species (TAGGART, 1981 ; Ferguson \& Fleming, 1983 ; Ryman, 1983 ; Krieg \& Guyomard, 1983) and several sympatric situations (Allendorf et al., 1976 ; Ferguson \& MAson, 1981 ; FERGUSON \& FLeming, 1983).

We have undertaken an extensive study of the genetic structure of wild brown trout populations from French rivers. Because of the importance of fish-farm production of brown trout and the possible effect of restocking practices on wild stocks, 
hatchery strains were also investigated. Electrophoretic variations of these populations are presented here.

Three major questions will be treated and discussed with respect to evolution and genetic management : (1) What is the genetic differentiation between major areas, the Atlantic and Mediterranean provinces, that could have been isolated for a relatively long period? (2) What is the level of differentiation within each area, i.e. the Mediterranean area considered as a high diversity zone for brown trout (BEHNKE, 1968) and the Atlantic area where evolutionary relationships between predominantly resident populations (e.g. Brittany) and predominantly anadromous populations (e.g. Normandy) have not been established yet? (3) How much of the genetic variability of the species is found in hatchery strains?

\section{Material and methods}

Origins and main characteristics of wild and hatchery stocks studied are reported in table 1. Hatchery stock sampling was based on the results of an inquiry made in brown trout fish-farms. This survey showed that about 80 p. 100 of the production or strains originated from less than 10 "pivot-hatcheries " (GuYOMARD, unpublished results). The 4 most important hatcheries were selected and studied (populations 1, 2, 3 and 6, table 1). A 5th important stock (Bidarray hatchery, Pyrénées atlantiques) was studied elsewhere (GuYomard et al., 1984). Moreover, populations 4 and 5, called "synthetic populations", resulted from crosses between spawners collected invarious hatchery stocks (including stocks 1, 2, 3 and 6).

Tissue samples were stored at $-30^{\circ} \mathrm{C}$ until electrophoretic analysis.

The following 23 enzymes were studied : AAT (aspartate aminotransferase), ADH (alcohol dehydrogenase), AGP ( $\alpha$-glycerophosphate dehydrogenase), AK (adenylate kinase), ALD (aldolase), CPK (creatine kinase), DIA (diaphorase), EST (esterases), FDP (fructose-1,6-diphosphatase), FUM (fumarase), IDH (isocitrate dehydrogenase), $\mathrm{LDH}$ (lactate dehydrogenase), MDH (malate dehydrogenase), ME (malic enzyme), 6-PGDH (6-phosphogluconate dehydrogenase), PGI (phosphoglucose isomerase), PGM (phosphoglucomutase), PMI (phosphomannose isomerase), P-ALB (para-albumin), SDH (sorbitol dehydrogenase), SOD (superoxide dismutase), TFN (transferrin), XDH (xanthine dehydrogenase). Electrophoretic and staining techniques for AK, ALD, CPK (only Cpk-3), DIA, EST, FDP, FUM and XDH are summarized in table 2. For all these enzymes, the staining components were dissolved in $15 \mathrm{ml}$ staining buffer, mixed to $10 \mathrm{ml} 2$ p. 100 agar staining buffer and poured over the gel layer. Electrophoretic procedures for the other enzymes were described elsewhere (GuYOMARD \& KRIEG, 1983). All these staining techniques were derived from HARRIS \& Hopkinson (1976), Allendorf et al. (1977), MAY (1980).

The locus and allele nomenclature followed the general recommendations proposed by Allendorf \& UTter (1979). Comparisons with results from other studies (TAgGaRT et al., 1981 ; RYMAN et al., 1979 ; RYMAN \& STAHL, 1981 ; RYMAN, 1983 ; FERGUSON \& Fleming, 1983) were based on a conservative approach described in previous papers (TAGgART et al., 1981 ; GUYOMARD \& KRIEG, 1983). 
TABLE 1

Origin and main characteristics of populations studied.

Origine et principales caractéristiques des populations étudiées.

\begin{tabular}{|c|c|c|c|c|c|c|}
\hline & Sample & $\begin{array}{c}\text { Year } \\
\text { of } \\
\text { sampl- } \\
\text { ing }\end{array}$ & Origin & $\begin{array}{l}\text { Sampling } \\
\text { location }\end{array}$ & $\begin{array}{l}\text { Sam- } \\
\text { ple } \\
\text { size }\end{array}$ & $\begin{array}{l}\text { Mean } \\
\text { age }\end{array}$ \\
\hline 1 & Magnet & 1981 & Italian Tyrol & Allier (hatchery) & 30 & 2 years \\
\hline 2 & Meysonnier & 1981 & Denmark & $\begin{array}{l}\text { Puy-de-Dôme } \\
\text { (hatchery) }\end{array}$ & 30 & 2 years \\
\hline 3 & Vermenoux & 1979 & Local rivers (4) & Yonne (hatchery) & 30 & 2 years \\
\hline 4 & Sy 79 & 1981 & $\begin{array}{l}\text { Progeny of spawners } \\
\text { from diverse hatcheries }\end{array}$ & $\begin{array}{l}\text { Experimental } \\
\text { hatchery }\end{array}$ & 39 & 2 years \\
\hline 5 & Sy 80 & 1982 & $\begin{array}{l}\text { Progeny of spawners } \\
\text { from diverse hatcheries }\end{array}$ & $\begin{array}{l}\text { Experimental } \\
\text { hatchery }\end{array}$ & 40 & 2 years \\
\hline 6 & Etrun & 1983 & Local rivers (4) & $\begin{array}{l}\text { Pas-de-Calais } \\
\text { (hatchery) }\end{array}$ & 40 & 2 years \\
\hline 7 & Polish & 1983 & Poland (vistula) (4) & Yonne (hatchery) & 40 & 2 years \\
\hline 8 & Orne Smolt (1) & 1982 & $\begin{array}{l}\text { Anadromous population } \\
\text { (natural reproduction) }\end{array}$ & $\begin{array}{l}\text { Orne river } \\
\text { (Normandy) }\end{array}$ & 30 & 1 year \\
\hline 9 & $\begin{array}{l}\text { Touques } \\
\text { Smolt (1) }\end{array}$ & 1982 & $\begin{array}{l}\text { Anadromous population } \\
\text { (natural reproduction) }\end{array}$ & $\begin{array}{l}\text { Touques river } \\
\text { (Normandy) }\end{array}$ & 25 & 1 year \\
\hline 10 & $\begin{array}{l}\text { Orne } \\
\text { Sea-Trout (1) }\end{array}$ & 1982 & $\begin{array}{l}\text { Anadromous population } \\
\text { (natural reproduction) }\end{array}$ & $\begin{array}{l}\text { Orne river } \\
\text { (Normandy) }\end{array}$ & 23 & 3 and + \\
\hline 11 & Orne $(1)$ & 1982 & $\begin{array}{l}\text { Resident population } \\
\text { (natural reproduction) }\end{array}$ & $\begin{array}{l}\text { Orne river } \\
\text { (Normandy) }\end{array}$ & $20-28$ & 2 and $t$ \\
\hline 12 & Calonne (1) & 1979 & $\begin{array}{l}\text { Anadromous population } \\
\text { (natural reproduction) }\end{array}$ & $\begin{array}{l}\text { Calonne river } \\
\text { (Normandy) }\end{array}$ & 20 & $2-5$ \\
\hline 13 & Hatchery Smolt & 1982 & $\begin{array}{l}\text { Etrun hatchery } \\
\text { (cf. pop. } 6 \text { ) }\end{array}$ & $\begin{array}{l}\text { Maritime zone of } \\
\text { Orne (Normandy) }\end{array}$ & 27 & 2 and $t$ \\
\hline 14 & Leffe (1) & 1983 & $\begin{array}{l}\text { Resident population } \\
\text { (natural reproduction) }\end{array}$ & $\begin{array}{l}\text { Leffe river } \\
\text { (Brittany) }\end{array}$ & 16 & 2 and + \\
\hline 15 & Kernec 82 & 1982 & $\begin{array}{l}\text { Resident population } \\
\text { (natural reproduction) }\end{array}$ & $\begin{array}{l}\text { Kernec river } \\
\text { (Britanny) }\end{array}$ & 15 & $1-1+$ \\
\hline 16 & Kernec $83(2)$ & 1983 & $\begin{array}{l}\text { Resident population } \\
\text { (natural reproduction) }\end{array}$ & $\begin{array}{l}\text { Kernec river } \\
\text { (Britanny) }\end{array}$ & 23 & $1-1+$ \\
\hline 17 & Haut-Scorff $(2)$ & 1982 & $\begin{array}{l}\text { Resident population } \\
\text { (natural reproduction) }\end{array}$ & $\begin{array}{l}\text { Scorff river } \\
\text { (Brittany) }\end{array}$ & 15 & $1-1+$ \\
\hline 18 & Elorn (3) & 1979 & $\begin{array}{l}\text { Resident population } \\
\text { (natural reproduction) }\end{array}$ & $\begin{array}{l}\text { Elorn river } \\
\text { (Brittany) }\end{array}$ & 30 & 2 \\
\hline 19 & Zivaco (3) & 1982 & $\begin{array}{l}\text { Resident population } \\
\text { (natural reproduction) }\end{array}$ & $\begin{array}{l}\text { Valle Tremoli river } \\
\text { (Corsica) }\end{array}$ & 11 & $3-4$ \\
\hline 20 & Aitone (2) & 1982 & $\begin{array}{l}\text { Resident population } \\
\text { (natural reproduction) }\end{array}$ & $\begin{array}{l}\text { Aitone river } \\
\text { (Corsica) }\end{array}$ & 9 & $2-3$ \\
\hline 21 & $\begin{array}{l}\text { Pont } \\
\text { des Condamnés }\end{array}$ & 1982 & $\begin{array}{l}\text { Resident population } \\
\text { (natural reproduction) }\end{array}$ & $\begin{array}{l}\text { Aitone river } \\
\text { (Corsica) }\end{array}$ & 11 & $2-3$ \\
\hline
\end{tabular}

(1) Frequent restocking - Repeuplement intense; (2) No information about restocking - Pas d'information sur le repeuplement; (3) No restocking - Absence de repeuplement; (4) Uncertain origin Origine incertaine. 
TABLE 2

Electrophoretic and staining procedures for some enzymes.

Technique d'électrophorèse et de révélation pour quelques enzymes.

\begin{tabular}{|c|c|c|c|c|c|}
\hline Enzyme & Tissu & $\begin{array}{l}\text { Electro- } \\
\text { phoretic } \\
\text { Buffer }\end{array}$ & $\begin{array}{l}\text { Stain } \\
\text { Buffer }\end{array}$ & Stain Components & $\begin{array}{c}\text { Genetic } \\
\text { determinism }\end{array}$ \\
\hline AK . . & $\mathbf{M}$ & MC 1 & TEA & $\begin{array}{rl}40 & \mathrm{mg} \text { Glucose ; } 30 \mathrm{mg} \mathrm{MgCl}_{2} \\
5 \mathrm{mg} \text { ADP ; } 2 \mathrm{mg} \text { NADP } \\
7 \mathrm{u} \mathrm{HK} ; 20 \mathrm{u} \mathrm{G} 6 \mathrm{PDH}\end{array}$ & Ak-1 and $2^{*}$ \\
\hline ALD & E & MC 1 & TEA & $\begin{array}{l}25 \mathrm{mg} \text { Fructose-1-6 diphosphate } \\
30 \mathrm{mg} \text { Arsenic acid } \\
40 \mathrm{u} \text { Glyceraldehyde- } \\
\text { phosphate dehydrogenase } \\
5 \mathrm{mg} \text { NAD }\end{array}$ & Ald \\
\hline CPK** & $\mathrm{E}$ & TCB 1 & TEA & $\begin{array}{l}10 \mathrm{mg} \text { Creatine phosphate } \\
30 \mathrm{mg} \text { Glucose } \\
5 \mathrm{mg} \text { ADP } ; 2 \mathrm{mg} \text { NADP } \\
5 \mathrm{u} \mathrm{HK} ; 20 \mathrm{u} \text { G6PDH }\end{array}$ & Cpk-3 \\
\hline DIA . & $\mathbf{L}$ & TCB 1 & TEA & Cf. Allendor F et al. (1977) & Dia \\
\hline EST $\ldots$ & $\mathbf{L}, \mathbf{M}, \mathbf{S}$ & TCB 1 & $\begin{array}{c}\text { TRIS- } \\
\text { MALEIC }\end{array}$ & Cf. KhanNa et al. (1975) & $\begin{array}{l}\text { Est- } 1 \text { and } 4: L \text {; } \\
\text { Est-2 }: \mathrm{M}, \mathrm{L}, \mathrm{S} \text {; } \\
\text { Est-3 and } 5: \\
\mathrm{M}, \mathrm{L}\end{array}$ \\
\hline FDP & $\mathbf{L}$ & $\mathrm{MC} 2$ & $\mathrm{~T}-\mathrm{HCl}$ & Cf. AlLendorf et al. (1977) & Fdp-1 and2 \\
\hline FUM . . & $\mathbf{M}$ & MC 1 & TEA & Cf. Allendorf et al. (1977) & Fdp-1 and 2 \\
\hline XDH .. & $\mathbf{L}$ & $\begin{array}{l}\text { TCB } 1 \\
\text { MC } 2\end{array}$ & TEA & Cf. Allendorf et al. (1977) & $\mathrm{Xdh}$ \\
\hline
\end{tabular}

* Undetermined number of loci - Nombre de locus non déterminé.

** For muscle CPK, use amido black stain - Pour la CPK du muscle, utilisation de noir d'amidon. The stain component abbreviations are those used by ALLENDORF et al. (1977). The electrophoresis and stain buffers were described in GuYOMARD \& KRIEG (1983). $2 \mathrm{mg}$ PMS and $10 \mathrm{mg}$ MTT were included in stains using NAD or NADP.

$\mathbf{E}=$ eye ; $\mathbf{L}=$ Liver ; $\mathbf{M}=$ muscle ; $\mathbf{S}=$ serum.

Les abréviations des produits de révélation sont celles utilisées par Allendorf et al. (1977). Les tampons d'électrophorèse et de révélation sont décrits dans GuYOMARD \& KRIEG (1983). 2 mg de PMS et $10 \mathrm{mg}$ de MTT sont inclus dans les révélateurs utilisant NAD ou NADP.

$E=$ ail $; L=$ foie $; M=$ muscle $S=$ serum. 
All the allele frequencies were determined by direct allele counting; for the duplicate loci, Aat-1,2, Cpk-1,2, Fum-1,2 and Mdh-3,4, the genetic interpretations of the electrophoregrams were based on the relative banding intensities. Whenever possible (i.e. more than 2 observations in every cell), Chi-square tests were performed for determining the gene frequency heterogeneity between populations. The same tests were applied for checking whether the genotype frequencies were in agreement with Hardy-Weinberg proportions.

Population heterozygosities, standard and minimum genetic distances were estimated according to NEI (1975).

The gene diversity analysis proposed by NeI (1973) and CHAKRABORTY (1980) was applied to our data; if all the populations have the same numerical weight, the total heterozygosity or gene diversity $(\mathrm{Ht})$ can be partitioned into 2 components, $\mathrm{Hp}$, the average population heterozygosity or gene diversity within populations and $\mathrm{D}_{\mathrm{T}}^{\mathrm{m}}$, the average minimal distance or gene diversity between populations. This partitioning can easily be extented to any degree of hierarchical subdivision (NEI, 1973). In this paper, the total gene diversity of wild populations will be subdivided into average gene diversity within population $(\mathrm{Hp})$, average gene diversity between populations within geographical group $\left(D_{P}^{m}\right)$ and the gene diversity between geographical groups $\left(D_{G}^{m}\right)$.

The dendrogram was generated by the UPGMA cluster analysis on standard genetic distances (SNEATH \& SOKal, 1973).

\section{Results}

Most of the systems studied have been previously analysed (AllENDORF et al., 1977 ; TAggart et al., 1981 ; GuYomard \& KrIEg, 1983 ; KRIEG \& Guyomard, 1983). Their description and genetic interpretation being similar from one author to another, only the systems showing a new polymorphism or electrophoretic pattern which differ from published interpretations will be described in detail.

AK : in the muscle, this system was always represented by 3 distinct invariant bands, instead of one in previous reports (ALLENDORF et al., 1977); however, we arbitrarily assumed AK to be coded for by one locus in this tissue.

ALD : only one invariant band was observed in the eye instead of 2 in previous studies (ALLENDORF et al., 1977).

FDP : AllENDORF et al. (1977) found an invariant 3 banded pattern for this enzyme in the liver and suggested a "two fixed loci " genetic model for a dimeric enzyme. This assumption proved to be correct by the di-allelic polymorphism observed at Fdp-1 in our samples and by the analysis of fullsib families (KRIEG, 1984) and gynogenetic lines (GUYOMARD, unpublished results).

FUM : cross breeding data showed that this system was coded for by 2 duplicated loci in the muscle (GuYOMARD, unpublished results). These 2 loci possessed a common allele Fum-1,2 (100); when both loci were fixed for this allele, muscle FUM 
electrophoregrams exhibited a two-banded pattern as desccribed by ALLENDORF et al. (1977). When variations occcurred at Fum-1,2, these 2 bands were replaced by 2 identical and sometimes overlapping multibanded patterns. Thus, one of these 2 bands (or groups of bands) represents either a heterotetramer product of Fum-1,2 and a 3rd locus, or an artefact; in our electrophoretic conditions, the 2 hypotheses were possible. Five alleles or more were observed at Fum-1,2 and the genetic basis of 3 of them [Fum-1,2 (100), (130) and (140)] was verified.

ME : in all the populations except ZIVAco, the fast moving supernatant ME exhibited a 5 banded pattern; cytosolic ME was therefore assumed to be coded for by 2 loci Me-3 and 4. The same genetic model was proposed by Vuorinen (1984) for supernatant $\mathrm{ME}$ in vendace (Coregonus albula L.).

SOD : variations involving 2 alleles were observed at Sod-1 in the liver and muscle. The enzyme encoded by this locus was tetrameric like the mitochondrial form in some other vertebrates (HARRIS \& HOPKINSON, 1976).

The genetic nature of the observed variations was proven for Aat-1,2, Agp-2, Cpk-1,2, Mdh-2, Mdh-3,4, Pmi-2 (GuYomard \& KrIEg, 1983), Aat-4, Fdp-1, Idh-3, Sdh-3, Sdh-1 (Krieg, 1984), Fum-1,2, 6-Pgdh-2 and Pgi-2 (GuYomard, unpublished results).

In the absence of breeding data, the genetic nature of the observed electrophoretic variation has been inferred for some loci under the following criteria (AllENDORF \& UTTER, 1979) : (1) electrophoretic variations conforming to the known molecular structure of the proteins; (2) consistent individual phenotypes from multiple tests of a tissue ; and (3) similar expression of the variant from different tissues of the same individual.

The 20 populations were systematically analysed for 46 loci. DIA and ALD have not been resolved clearly enough in all populations. Variations at Est-3 were difficult to interpret. The tetrameric structure of FUM and the high number of alleles at Fum1,2 complicated the identification of all the genotypes and did not permit an accurate frequency estimation in most hatchery and Norman populations. In these populations, Fum-1,2 (70) was never observed.

Allele frequencies are reported in table 3. 21 loci were monomorphic in all populations. On the contrary, the allele frequency variations ranged from 0 to 1 at 11 loci (Cpk-1, Est-4, Est-5, Fdp-1, Ldh-3, Ldh-5, Mdh-2, Me-1, Me-4, Pmi-2 and Sdh-2). Some populations possessed some unique alleles at frequencies close to one (fig. 1). Thus, a large genetic heterogeneity is clearly present in French brown trout.

Hardy-Weinberg proportions were tested in all the populations. Only Orne (pop. 11) showed a significant deviation from the Hardy-Weinberg equilibrium (Chi-square values summed over Aat-4, Fdp-1, Mdh-3,4, Sdh-1).

This deviation, mainly explained by an excess of Mdh-3,4 (100/100/75/50) and a deficit of Mdh-3,4 (100/100/100/50) genotypes, was significant in 3 cases, (1) only Mdh-3 or Mdh-4 polymorphic $(p<0.01)$, (2) both loci polymorphic with the same allele frequencies $(p<0.005)$, (3) both loci polymorphic with the allele 75 occurring only at Mdh-3 and allele 50 only at Mdh-4 ( $\mathrm{p}<0.005)$.

Loci at which significant gene frequency differences were found are given in table 4. Four major "statistical zones » appeared : Brittany (pop. 15-18), Normandy- 


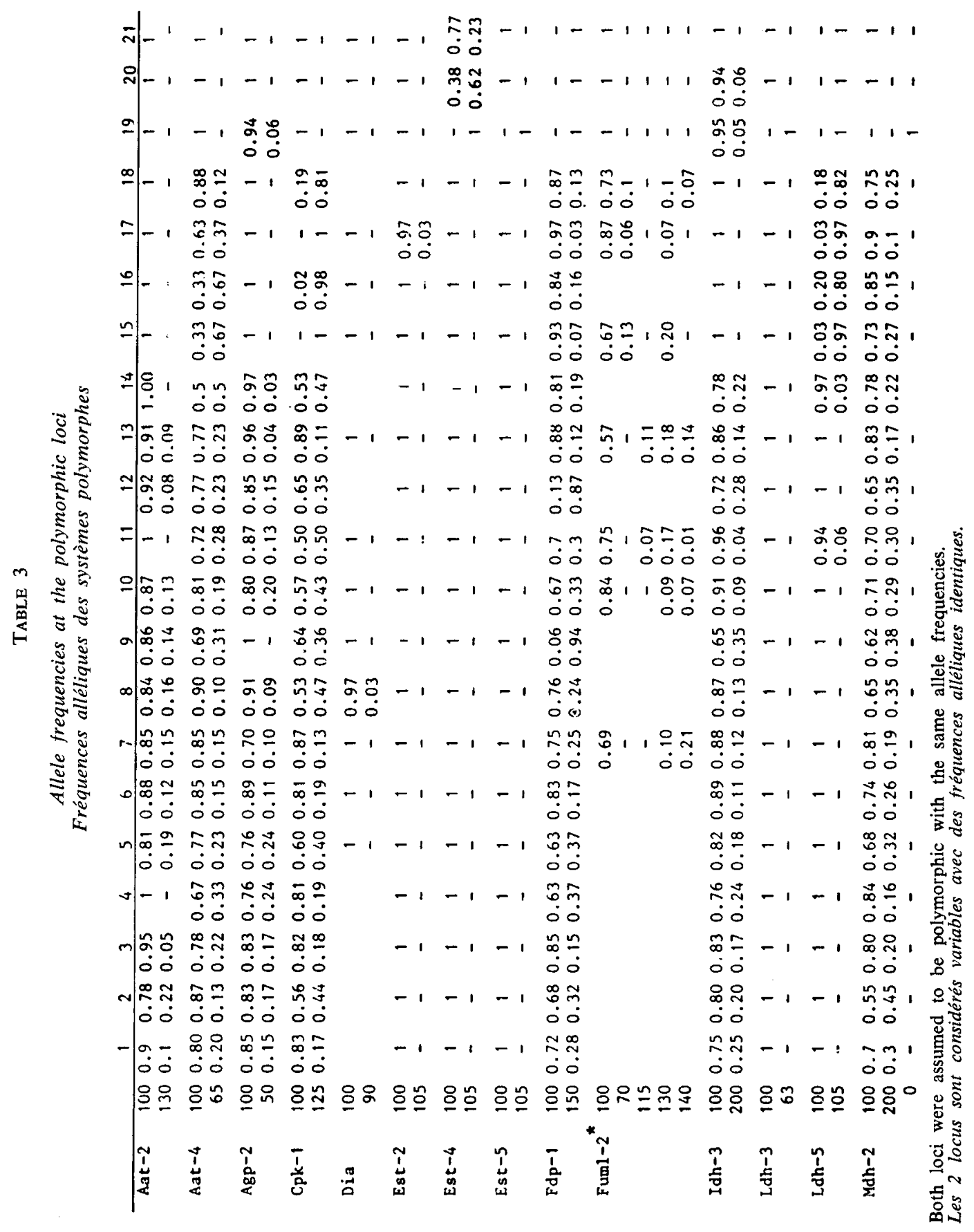




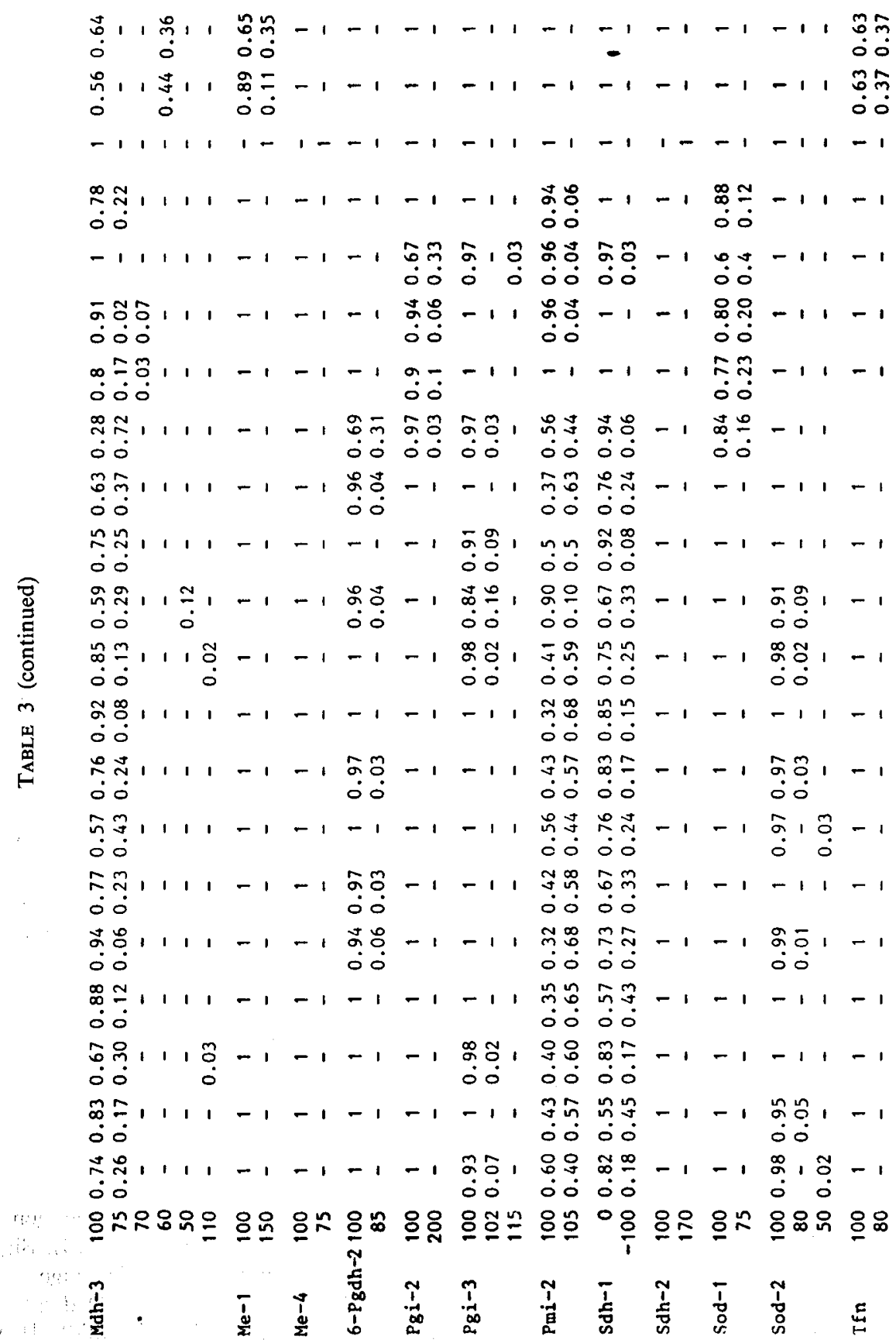




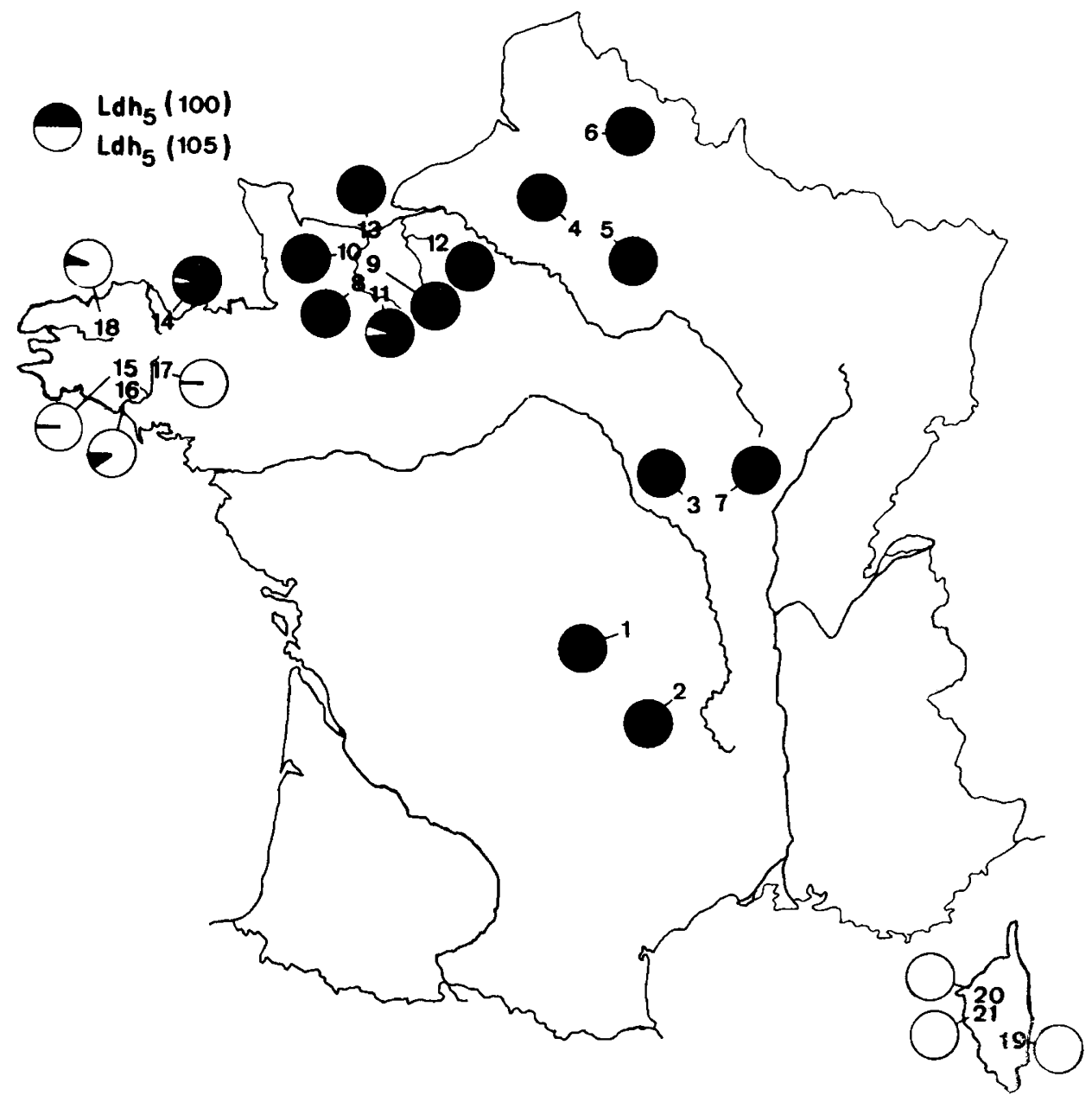

FIG. 1

Geographical variation in frequency of Ldh-5 alleles (population numbers correspond to table 1).

Variation géographique des fréquences des différentes allèles de Ldh-5 (les numéros des populations correspondent à ceux du tableau 1).

Hatchery (pop. 1-13), Evisa (pop. 19 and 20) and Zicavo (pop. 21). Some genetic heterogeneity was found within the "Normandy-Hatchery » cluster (pop. 1-13). Significantly different allele frequencies between samples within the same drainage were found only in the Orne river ; Orne sea-trout (pop. 10) and Orne (pop. 11) displayed statistically significant differences at $4 \mathrm{loci}$, Aat-2, Mdh-3, Pgi-3 and Pmi-2. If we assume that the 2 samples belong to the same reproductive unit, the frequency heterogeneity would mean that (1) there is genetic variability within the population for 


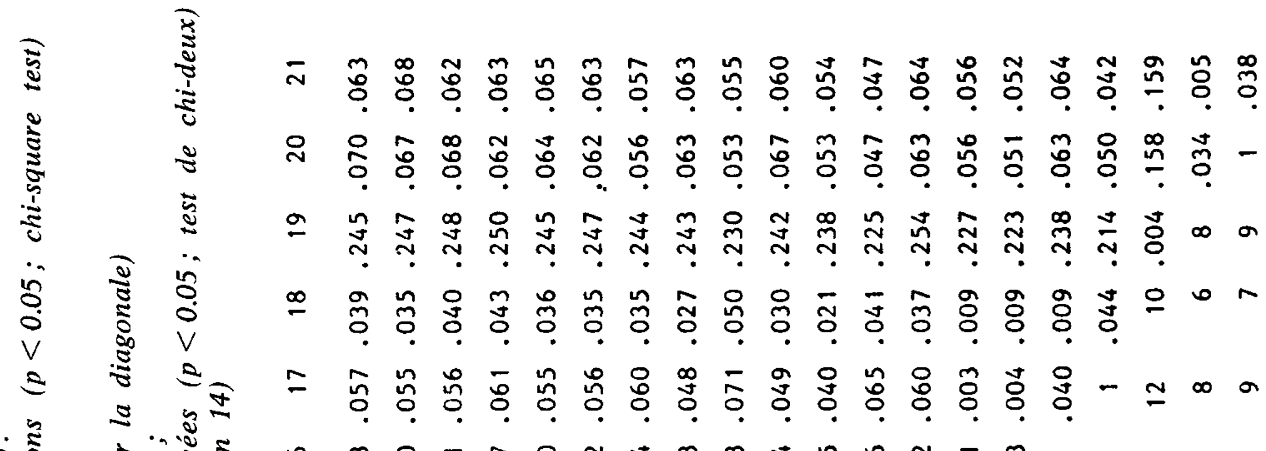
₹

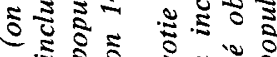

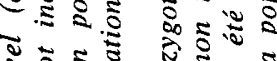

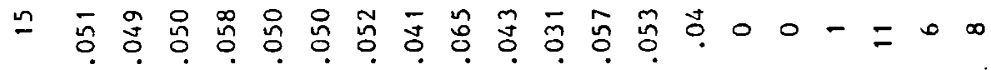
-

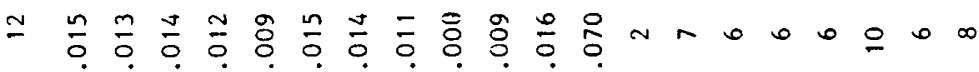

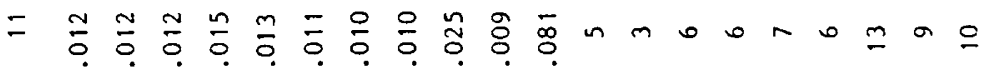

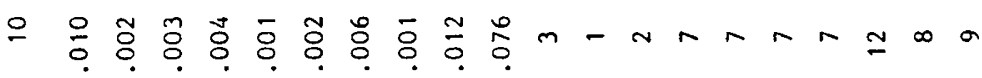
$a \frac{0}{0} \frac{0}{0} \frac{m}{0} \frac{m}{0} \frac{\infty}{0} \frac{\overline{0}}{0} \frac{n}{0} \frac{0}{0} m n-m \sim \infty \sim \infty \simeq \infty a$

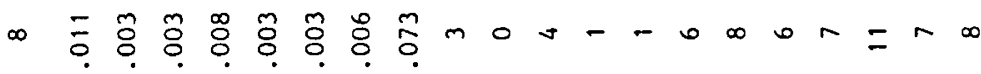
-

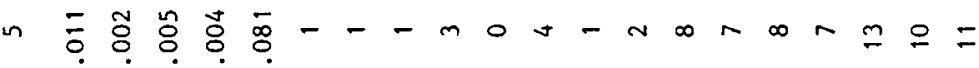
-

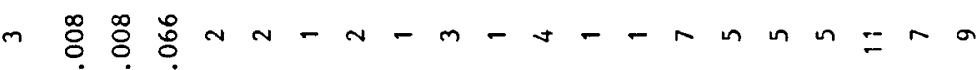

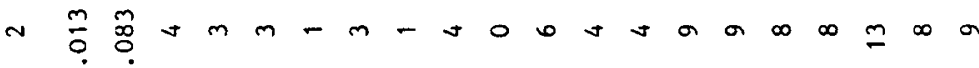
इ ㅎํำ

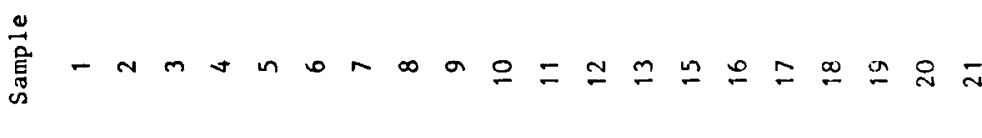


the anadromous-sedentary character, (2) Aat-2, Mdh-3,4, Pgi-3 and Pmi-2 are linked to " anadromous-sedentary " genes. As linkages between so many protein loci and possible " anadromous-sedentary " genes are unlikely, gene frequency differences between Orne (pop. 11) and Orne (pop. 10) sea-trout will rather be interpreted as resulting from the mixture of differentiated genic pools.

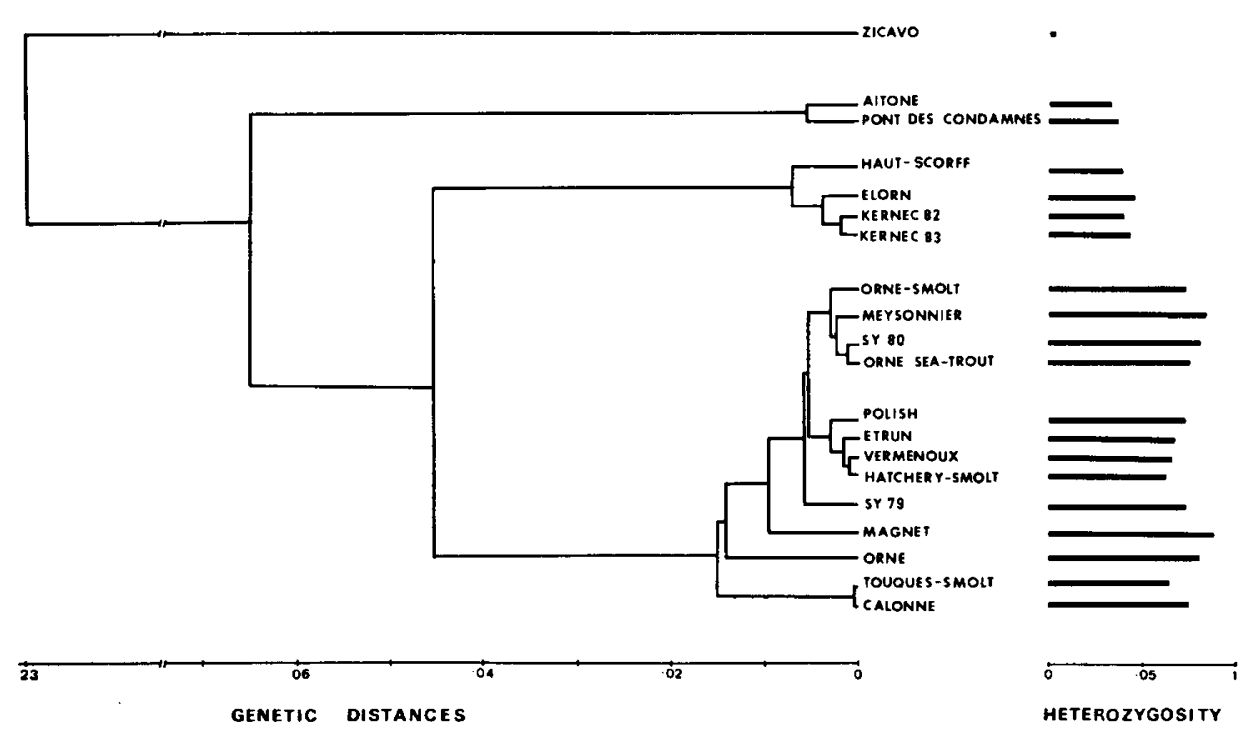

FIG. 2

Dendrogram produced by UPGMA cluster analysis of NeI's standard genetic distances and heterozygosities (based on data from table 4).

Dendrogramme obtenu par agglomération hiérarchique UPGMA des distances génétiques standard de NeI et taux d'hétérozygotie (basés sur les données du tableau 4).

The high level of geographic differentiation between wild populations as well as the existence of geographical groups were well evidenced by the genetic distances, heterozygosities, dendrogram (tabl 4, fig. 2) and hierarchical analysis of the total gene diversity (fig. 3). Fifty p. 100 of the genetic variability was between groups and only 6 p. 100 between populations within groups. By contrast, the hatchery strains exhibit a relative genetic identity $\left(D_{T}^{m} / H_{T}=6\right.$ p. 100). There was a rather high similarity between hatchery and Norman populations. 

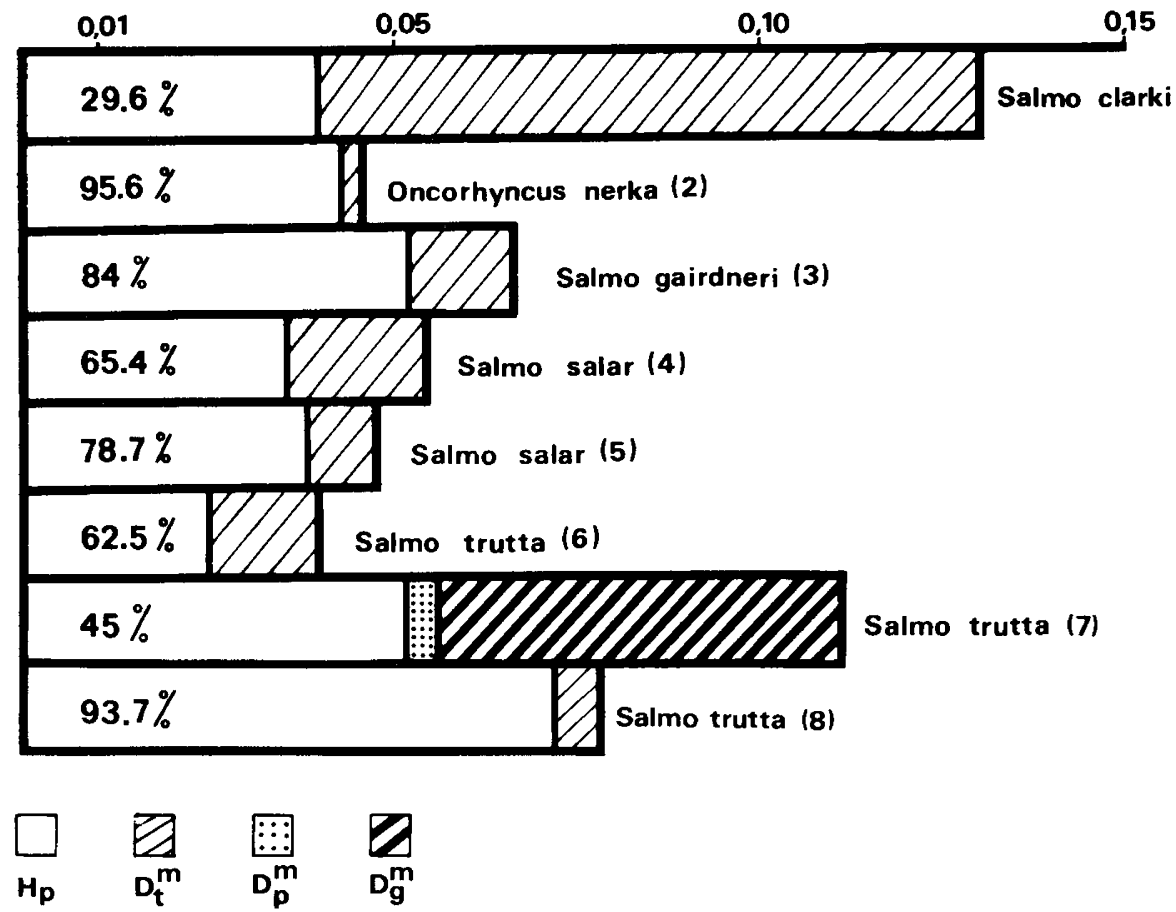

FIG. 3

Gene diversity analysis in 5 species of salmonids.

Analyse de la diversité génique chez 5 espèces de salmonidés.

Hp : Average gene diversity within population; $D_{G}^{\mathrm{m}}$ : Average gene diversity between geographical groups (only reported for our study); $D_{\mathrm{P}}^{\mathrm{m}}$ : Average gene diversity between populations within geographical groups $; D_{\mathrm{s}}^{\text {n }}$ : Average gene diversity between populations; (1) Loudenslager \& Gall, $1980: 24$ populations, 35 loci ; (2) Reviewed by Ryman, 1983 : 18 populations, 26 loci ; (3) Reviewed by RYMan, 1983: 38 populations, 16 loci ; (4) Data from Cross (including canadian populations), 1982; RYMAN, 1981; GuYomaRD (unpublished results) : 10 populations, 32 loci ; (5) Same data as (4) without canadian populations : 8 populations, 32 loci ; (6) RrMan, 1983 : 35 populations, 35 loci ; (7) Our study : 12 wild populations, 46 loci ; (8) Our study : 8 hatchery populations, 46 loci.

$H p$ : Diversité génique moyenne intrapopulation; $D_{G}^{m}$ : Diversité génique moyenne entre groupes géographiques (uniquement pour notre étude); $D_{P}^{m}:$ Diversité génique moyenne entre populations intragroupe géographique; $D_{T}^{m}:$ Diversité génique moyenne entre populations; (1) LoUdenslaGER \& GALL, 1980:24 populations, 35 locus; (2) Dans RYMAN, 1983 : 18 populations, 26 locus; (3) Dans RYMAN, 1983 : 38 populations, 16 locus; (4) Données de Cross (populations canadiennes comprises), 1982 ; de RYMAN, 1981 ; de GuYomard (résultats non publiés) : 10 populations, 32 locus ; (5) Données identiques à (4) à l'exclusion des populations canadiennes : 8 populations, 32 locus; (6) RYMAN, 1983: 35 populations, 35 locus; (7) Notre étude : 12 populations naturelles, 46 locus; (8) Notre étude : 8 populations domestiques, 46 locus. 


\section{Discussion}

\section{A. Geographical differentiation between wild populations}

Although the lack of identical electrophoretic conditions or enzyme sample precludes a rigourous comparison of published data from different laboratories, 2 major points may be emphasized in the comparative hierarchical analysis of the genetic variability of closely related salmonid species (fig. 3), i.e. (1) the high level of total gene diversity $\left(\mathrm{H}_{\mathrm{T}}=0.112\right.$; fig. 3$)$ and (2) the high relative magnitude of gene diversity between wild populations $\left(D_{G}^{m}+D_{P}^{m} / H_{T}=55\right.$ p. 100 ; fig. 3) in brown trout. This large amount of relative divergence between brown trout populations was previously pointed out (RYMAN, 1983). Our results mainly differ from published information by the higher absolute values reported here, but, as mentioned before, this apparent discrepancy could reflect differences in the electrophoretic procedures used as well as in the intrinsic characteristics of the populations studied.

Due to the small number of sampled populations, it is impossible to determine whether the 4 clusters we observed correspond to a clearcut geographical differentiation or only express the sampling discontinuity of the populations.

The local origin of Zivaco (pop. 19) and Evisa (pop. 20 and 21), is supported by their large electrophoretic divergence from the hatchery strains studied (GuYoMARD et al., 1984 ; this paper; GUYOMARD, unpublished results) which have been the only strains used for restocking Corsican drainages. Two hypotheses might explain the large genetic distance between Zivaco and Evisa. On the one hand, this distance is characteristic of salmonid populations from well-distinct genic pools, considered as species (SMIth, 1981) or subspecies (Loudenslager \& Gall, 1980). As differentiation events and local colonization events seem to have been frequent in the mediterranean area (BEHNKE, 1968), Zivaco and Evisa might belong to 2 distinct forms which could have invaded the Corsican drainages. On the other hand, the low heterozygosity level of Zivaco suggests that the large electrophoretic divergence between the 2 samples might result from severe genetic drift or selection events and represent an extreme situation. In such a case, additional studies could reveal intermediate populations so that no obvious dichotomy would appear between Corsican populations. In fact, both multiple colonization and full intergradation might have occurred during the recent evolution of Corsican stocks. Evisa which, to some extent, is intermediate between continental and Zicavo populations (table 4) could be an intergraded form between northern and meridional "Zivaco-like" (but more polymorphic) populations.

A meridional subspecies, Salmo trutta macrostigma, has been distinguished from northern populations by fewer pyloric caeca, vertebra and gill rakers (BEHNKE, 1968). Its native range is thought to include Corsica (Roule, 1933 ; Splllman, 1961). Our electrophoretic data confirm to some extent the originality of Corsican populations suggested by some meristic studies. However, it seems premature and perhaps meaningless to assign Evisa (pop. 20 and 21), Zivaco (pop. 19) or any other Corsican population to Salmo trutta macrostigma, on the sole basis of their large electrophoretic differentiation from continental stocks. As recent works (OLIVARI \& BRUN, in press) have shown that the number of pyloric caeca in some Corsican populations could be more variable and higher than previously reported, a first simple 
caution is to check these populations for the discriminant characters. Moreover, the morphological similarities on which the Salmo trutta macrostigma concept is based might rather reflect an adaptative or epigenetic convergence than taxonomic relationships.

The remaining wild populations can be divided into 2 well differentiated Norman and Breton groups, but a clinal or more complicated pattern of geographical variations could possibly emerge from a systematic sampling between Orne and Elorn rivers. Breton wild populations differ considerably from hatchery populations and could be considered as native. On the contrary, the Norman populations are close to the domesticated strains so that hatchery introgression and contamination cannot be excluded.

Ferguson \& Flemming (1983) have hypothesized the existence of 2 geographical races in the British Isles, an " ancestral trout » and a " migratory trout " possessing Ldh-5 (105) and Ldh-5 (100) respectively, at very high frequencies. These authors also suggested that these 2 races could have undergone their differentiation during the WURM III phase of the last glaciation. South-Brittany and Norman populations fixed for Ldh-5 (105) and Ldh-5 (100) respectively could be the French counterparts of the 2 British " races". However, their existence as well as their taxonomic relationships with the French populations are based on variations at a single locus and are still highly speculative.

Allele frequency variation at some loci (e.g. Ldh-1, Mdh-3,4, Sdh-1 and Pgi-3) in Scandinavian stocks (RYMAN et al., 1979 ; RYMAN, 1983) also suggest large genetic differentiations between some of these stocks and French populations.

The different heterozygosity levels between populations from different clusters could reflect differences in the effective size of the populations. Slightly lower estimates of heterozygosity were obtained by other authors (FERGUSON \& FLEMING, 1983 ; Ryman \& STAHL, 1981 ; Ryman, 1983) but this does not necessarily reflect intrinsic differences between populations. The quite identical homozygosity levels as well as the small genetic distances within the Norman and Breton clusters suggest that no severe bottleneck effect had occurred in these populations.

\section{B. Ecological differentiation}

In Orne river, an analysis of migratory (pop. 8 and 10) and resident (pop. 11) samples collected in the same area evidenced 2 electrophoretically differentiated stocks. This is the only noticeable case of genetic differentiation within a drainage found in this study. Moreover, if some intra-population variability for resident-migratory behaviour exists, the 2 stocks could have contaminated each other and the genetic distance between them could have been underestimated. Sympatric anadromous and resident populations were found in Irish lake systems (CROzIER, 1983), but they were only self-sustained populations. In Orne river, the resident stock is naturally reproducing. On the other hand, Orne sea-trout (pop. 10) and Orne smolt (pop. 8) were quite similar to the hatchery strain used for restocking and could mainly represent artificially propagated stocks. So, the behavioural differences between Orne sea-trout (pop. 10) and Orne (pop. 11) could rather reflect environmental differences in the early stage fo development (i.e. natural versus artificial conditions) than genetic differences between stocks. 
The discrepancy between observed and expected genotype frequencies at Mdh-3,4 in the Orne sample might simply result from a mixture of genetically differentiated stocks. In such a case, deviations from Hardy-Weinberg proportions are observed during the 1 st generation and non-random associations between alleles at different loci are generated for several generations (LI, 1955 ; MAKELA \& RichaRdson, 1977). Owing to the indetermination of the allele frequencies at Mdh-3 and 4, and the small size of Orne sample, we did not test this hypothesis of mixed stocks.

\section{Origin of hatchery strains and management implications}

As 70 p. 100 of the hatchery stocks used originated from the hatchery strains we studied (GuYomARD, unpublished data), it may be concluded that domesticated stocks are highly similar. Two hypotheses may account for this relative similarity :

- a selection towards a "domestic type", an instantaneous selection if some wild populations do not stand the "breeding conditions" or a progressive one over several generations ;

- an initial sampling of the hatchery strains in a restricted area of the species range. There are electrophoretic (Allendorf, 1975), karyological (ThorgaARD, 1983) and historical (MACCRIMMON, 1971) evidences for such a "founder " effect in domesticated rainbow trout which predominantly originated from trout native to Sacramento river tributaries in northern California. It is to be feared that the original area of the domesticated brown trout is now highly modified by intensive restocking in Europa.

When released in some rivers, these hatchery strains can also exhibit some anadromous trends (RICHARD, personal communication), but environmental as well as genetic factors might explain this feature.

Some practical conclusions may be drawn from our results for the utilisation and management of genetic variability. First, hatchery populations only exhibit 50 p. 100 of the total variability of the species, and wild populations should be included in selection programmes. Secondly, a repeated use of hatchery strains could lead to a marked depletion of genetic variability. In addition, these strains might not be adapted to all ecological conditions. On the basis of the geographical clusters found in this study, very simple preliminary preservation programmes of local populations could be proposed : restocking practices should be prevented in areas such as West Brittany and some parts of Corsica. However, it is possible that further studies in new drainages or analysis of the intracluster variability for other characters such as quantitative characters and chromosomal polymorphism would reveal a more complex genetic structure and call for a more sophisticated management strategy.

\section{Acknowledgements}

We would like to thank the Parc Régional de Corse, the Fédérations Départementales du Calvados, des Côtes du Nord, du Finistère et du Morbihan, the C.N.E.X.O., the Délégation Régionale du C.S.P. (Rennes), the Laboratoire de Physiologie des Poissons (I.N.R.A., Rennes) and Laboratoire d'Ecologie Hydrobiologique (E.N.S.A., Rennes) for their cooperation in obtaining samples of brown trout. This study was supported by grants from the Conseil Supérieur de la Pêche. 


\section{References}

AllendorF F.W., 1975. Genetic variability in a species possessing extensive gene duplication : genetic interpretation of duplicate loci and examination of genetic variation in populations of rainbow trout. Ph.D. Thesis, University of Washington, Seattle.

Allendorf F.W., Ryman N., Stennek A., Stahl G., 1976. Genetic variation in scandinavian brown trout (Salmo trutta L.) : evidence of distinct sympatric populations. Hereditas, 83, 73-82.

Allendorf F.W., Mitchell N., Ryman N., Stahl G., 1977. Isozymes loci in brown trout (Salmo trutta L.) Detection and interpretation from population data. Hereditas, 86, $179-190$.

Allendorf F.W., Utter F.M., 1979. Population genetics. In : Randall D.J., Hoar J.S., Brett R. (ed). Fish Physiology, vol. 8, 407-454, Academic press, New York.

Allendorf F.W., Phelp S.R., 1981 b. Isozymes and the preservation of genetic variation in salmonid fishes. In : Ryman N. (ed.). Fish Gene Pools. Ecol. Bull., (Stockholm), 34, $37-52$.

BEHNKE R.J., 1968. A new subgenus and species of trout, Salmo (Platysalmo) platycephalus, from southcentral Turkey, with comments on the classification of the subfamily salmoninae. Mitt. Hamburg. Zool. Mus. Inst., 66, 1-15.

BEHNKE R.J., 1972. The systematics of salmonid fishes of recently glaciated lakes. J. Fish. Res. Board. Can., 29, 639-671.

Chakraborty R., 1980. Gene diversity analysis in nested subdivided populations. Genetics, 96, 721-726.

Cross T.F., 1982. Biochemical genetics, Section E. Annual Report of the Salmon Research Trust of Ireland, 27, 59-60.

Crozier W.W., 1983. Population biology of Lough Neagh Brown trout (Salmo trutta L.). Thesis Ph.D., The Queen's University, Belfast.

Ferguson A., Mason F.M., 1981. Allozyme evidence for reproductively isolated sympatric populations in brown trout (Salmo trutta L.) in Lough Melvin, Ireland, J. Fish. Biol., 18, 629-642.

Ferguson A., Fleming C.C., 1983. Evolutionary and taxonomic significance of protein variation in the brown trout (Salmo trutta L.) and other salmonids. In : OxFORD G.S., Rollinson D. (ed.), Protein polymorphism : adaptative and taxonomic significance, 86-99, Academic press, London.

GeldiaY R., 1982. Trout (Salmo trutta L.) populations inhabiting the streams of Kazdagi Range. Verh. Internat. Verein. Limnol., 18, 1212-1221.

GUYOMARD R., KRIEG F., 1983. Electrophoretic variation in six populations of brown trout (Salmo trutta L.). Can J. Genet. Cytol., 25, 403-413.

Guyomard R., Grevisse G., Oury F.X., Davaine P., 1984. Evolution de la variabilité génétique inter et intrapopulation de populations de salmonidés issues de mêmes pools géniques. Can. J. Fish. Aquat. Sci., 41, 1024-1029.

HarRis H., Hopkinson D.A., 1976. Handbook of enzyme electrophoresis in human genetics. North-Holland, Oxford.

KRIEG F., Guyomard R., 1983. Mise en évidence électrophorétique d'une forte différenciation génétique entre populations de truite fario de Corse. C.R. Acad. Sci. Paris, 296, 1089-1094.

KRIEG F., 1984. Recherche d'une différentiation génétique entre populations de Salmo trutta. Thèse de $3^{\mathrm{e}}$ cycle, Université de Paris-sud, Orsay.

Li C.C., 1955. Population genetic. 366 pp. University of Chicago Press. Chicago.

Loudenslager E.J., Gall G.A.E., 1980. Geographic patterns of protein variation and subspeciation in cutthroat trout (Salmo clarki). Syst. Zool., 28, 27-42.

MacCrimmon H.R., Marshall T.L., 1968. World distribution of brown trout, Salmo trutta. J. Fish. Res. Board. Can., 25, 2527-2548. 
MacCrimmon H.R., 1971. World distribution of rainbow trout (Salmo gairdneri). J. Fish. Res. Board. Can., 28, 663-704.

Makela M.E., Richardson R.H., 1977. The detection of sympatric sibling species using genetic correlation analysis. I. Two loci, two gamodemes. Genetics, 86, 665-678.

MAY B., 1980. The salmonid genome : evolutionary restructurating following a tetraploid event. Thesis Ph.D. Pennsylvania State University.

MAYr E., 1973. Populations, espèces et évolution. 496 pp., Hermann, Paris.

NEI M., 1973. Analysis of gene diversity in subdivided populations. Proc. Nat. Acad. Sci., 70, 3321-3323.

NEI M., 1975. Molecular population genetics and evolution. 228 pp., North-Holland, Amsterdam \& New York.

Olivari G., Brun G., 1984. Le nombre de caeca pyloriques dans les populations naturelles de truites en Corse. Actes du colloque international sur les vertébrés terrestres et dulçaquicoles des îles méditerranéennes. (In press).

Rovle L., 1933. Le peuplement des cours d'eau de la Corse en poissons. Bull. Fr. Piscic., 63, 61-62.

Ryman N., 1983. Patterns of distribution of biochemical genetic variation in salmonids : differences between species. Aquaculture, 33, 1-21.

Ryman N., Allendorf F.W., Stahl G., 1979. Reproductive isolation with little genetic divergence in sympatric populations of brown trout (Salmo trutta). Genetics, 92, 247-262.

Ryman N., Stahl G., 1981. Genetic perspectives of the identifications and conservation of Scandinavian stocks of fish. Can. J. Fish. Aquat. Sci., 38, 1562-1575.

SмiтH R.C., 1981. Biochemical genetics and meristic analysis of populations of little Kern river basin golden trout. THESIS Ph.D., University of California, Davis.

Sneath P.H.A., SOKal R.R., 1973. Numerical taxonomy. 573 pp., Freeman W.H. and Co., San Francisco.

Spillman C., 1961. Faune de France, poissons d'eau douce. 291 p., Lechevalier, Paris.

SPIETH P.T., 1974. Gene flow and genetic differentiation. Genetics, 78, 961-965.

TAgGart J.B., 1981. An electrophoretic study of genetic variation in Irish brown trout (Salmo trutta $L$.). ThesIS Ph.D. The Queen's University, Belfast.

Taggart J., Ferguson A., Mason G.M., 1981. Genetic variation in Irish populations of brown trout (Salmo trutta L.) : electrophoretic analysis of isosymes. Comp. Biochem. Physiol., 698, 393-412.

ThorgaARD G.H., 1983. Chromosomal differences among Rainbow trout populations. Copeia, 650-662.

ThORPE J.E., Mitchell K.A., 1981. Stocks of Atlantic salmon (Salmo salar) in Britain and Ireland : discreteness and current management. Can. J. Fish. Aquat. Sci., 38, 1576-1590.

VuORINEN J., 1982. Little genetic variation in the Finnish Lake Salmon, Salmo salar sebago (Girard). Hereditas, 97, 189-192.

VUORINEN J., 1984. Duplicate loci for supernatant and mitochondrial malic enzymes in vendace, Coregonus albula (L.). Comp. Biochem. Physiol., 78 B, 63-66. 